\title{
LITHUANIAN DIASPORA ROLE IN SUSTAINABLE DEVELOPMENT OF COUNTRY
}

\author{
Ingrida GeČIEnÉ ${ }^{1}, \breve{S}_{\text {ARŨNAs Matulaitis }}^{2}$ \\ Institute of Social Innovations (Lithuania)
}

\begin{abstract}
The world wide experience of communication and cooperation of diasporas and origin countries shows various ways and forms how diasporas can contribute towards sustainable development of origin country. Lithuania also has relatively huge diaspora and faces increasing emigration every year. However, it still neglects the potential of it's diaspora involvement in contributing to well-being of the country. In order to reveal the potential of Lithuanian diaspora the qualitative research was conducted. It used expert interview method with 12 leaders of foreign Lithuanian communities and organizations. The research revealed that Lithuanian diaspora is willing and could contribute significantly to the country's sustainable development in various areas: scientific, business, cultural and social ones. In order to facilitate this cooperation, Lithuanian government should decrease barriers for cooperation and implement measures that would take into account the diversity of diaspora groups interests and possibilities, provide relevant information about means of engagement and support already existing and new diaspora networks and their initiatives.
\end{abstract}

KEYWORDS: Lithuanian diaspora, international cooperation, sustainable development, regional development

JEL CODES: Q010, Q560

\section{Introduction}

Lithuanian Strategy for Sustainable Development, that seeks to mobilize citizens for sustainable development in the main scientific, economic and social areas, is more focused on the country's inner potential. However, one can notice that within 20 years of independence, more than 0.5 million people have left Lithuania. According to some assessments, about one million persons of Lithuanian origin are currently living outside of Lithuania (Lithuanian Foreign communities), the Lithuanian diaspora has huge potential to contribute to the country's sustainable development.

Lithuanian diaspora in this article is defined as a foreign resident Lithuanian part of the nation, consisting of citizens of the Republic of Lithuania and Lithuanian descent, as well as non-Lithuanian descent, originating themselves from Lithuania, and connecting themselves with Lithuania's historical, cultural, social, economic and political ties. Usually, the notion of "diaspora" seems to better incorporate populations that are "settled" abroad, people who became citizens of their host country and second-born generations (Iones$\mathrm{cu}, 2006$ ). However nowadays, only a small part of people who emigrate to the foreign countries tend to cut all connections with home country. Therefore, a number of academic authors tend to use the notion of "transnational communities" instead of diaspora to emphasize the idea of movement and exchange between home and host countries, and to attract attention to the existence of informal networks. In this paper into term

1 Ingrida Genienè - Institute of Social Innovations, Vilnius University, Faculty of Communication and Lithuanian social research center. Scientific interest: sociology.

E-mail: gecieneingrida@gmail.com

Tel.: +37068621641.

2 Šarūnas Matulaitis - Institute of Social Innovations. Scientific interest: sociology.

E-mail: matulaitis.sarunas@gmail.com

Tel.: +3706 7405202 . 
"diaspora" authors incorporate the shifting networks of diaspora members who form or take part in various host and origin country communities and networks abroad.

Most countries, what suffer from extensive emigration, usually emphasize the losses for the country: decreasing work power, brain drain, decreasing tax collection, aging society, etc. Nevertheless, some authors reveal positive consequences: origin countries can gain by easing unemployment as well as banking the remittances, investments and knowledge transfers of engaged emigrants (Gamlen, 2006). Besides, contribution to home country's development is possible not only through financial investment, trade, etc. but also through non-financial means (technical and business skills, know-how, useful connections, etc.).

This article aims to reveal the Lithuanian diaspora potential of contributing to the well-being of the country. To this aim, the article discusses the benefits of cooperation with the diaspora in the context of promoting sustainable development, presents the forms of diaspora assistance to the country and uses the 2012 research results to present the Lithuanian diaspora potential to contribute to the well-being of the country $(\mathrm{A} / \mathrm{N}-$ the study was commisioned by LR Prime Minister's Office for the European Social Fund funded project for Lithuania's EU Affairs of the system efficiency).

This article is based on the latest scientific studies (Johnson and Sedaca, 2004; Kuznecov, 2006; Ionesku, 2006; Gamlen, 2006, 2009, 2011 and other) that analyze the cooperation forms and areas were diaspora could contribute to the sustainable development of the country. These perceptions are further carried out by Lithuanian diaspora possibilities to contribute to the well-being of the state research that reveals potential means of Lithuanian diaspora involvement in the country's sustainable development. The study used expert interviews with heads of Lithuanian communities abroad, representatives of diaspora organizations, and returned active members of the diaspora.

\section{Means of diaspora contribution to the countries of origin}

The global economy and increasing emigration helps to create favorable conditions for the formation of diasporas. The struggle for talent and the brain, as the main factors of advanced and developing society guarantors, is going through the various emigration and immigration, education and business and other policies, creating favorable conditions for the development of diasporas (Kuznecov, 2006: 3). Following Gamlen, this article approaches "diaspora" as "an umbrella term for the many extraterritorial groups that, through processes of interacting with their origin state, are in various stages of formation" (Gamlen, 2009: 4). This approach emphasizes that diasporas are not homogenous entities and include:

- temporary or transnational migrants who spread their time between their sending state and elsewhere and fall more or less arbitrarily into one or other policy category of the origin state;

- longer-term but still first-generation emigrants settled in another country;

- descendants of emigrants who - in certain places at certain times - identify as diasporic or even as members of a fully fledged diaspora "community".

Diaspora individuals and diaspora-organized entities are extremely varied. According to Ionescu, decision makers willing to collaborate with diaspora in home and host countries "are faced with a multitude of interlocutors who often represent diverse interests". For home country policies engaging diasporas for development to be realistic and effective, the home country's development strategy and the particular choice of diaspora members willing to engage themselves either for motives of philanthropy or profit, in particular development activities in their home countries, has to be compatible and mutually supportive (Ionescu, 2006: 27). These different forms of cooperation and communication can become quite a substantial factor in order to reinforce sustainable development strategies for engaging the diaspora in the economic, scientific, and other fields in different world regions and individual countries. However, this potential is often overlooked in countries of origin and therefore it is not included in domestic policy plans.

Foreign good experience in promoting cooperation with diaspora nearly has not been studied in Lithuania so far. The only survey conducted by the Institute of Social Innovations under the project of Lithuanian 
Foreign Support Center "Brain Drain program design and implementation" in this field analyzes scientists and researchers experience attraction strategies in foreign countries. This study analyzes the experience of 11 countries in collaboration with scientists from the diasporas. Study revealed that the foreign countries, especially smaller ones (such as Finland, Switzerland), focused on brain exchange and cooperation with scientists however, bigger ones are more concentrated to brain attraction. As it was noticed the members of diaspora are often involved in development of their country through research collaboration and through investment (The task for Lithuania - from brain drain to brain attraction, 2008).

Investing in your origin country is one of the main support forms for the country's development from diaspora: diasporas in China, India and Israel played an important role in attracting foreign direct investment then the investments in these countries were considered too risky (Kuznecov et al., 2003). However, as Gamlen emphasize, the biggest economic impact of diasporas for origin countries are made by remittances. The significance of remittances has become a cornerstone of migration and development studies: "To repeat one of the best known development mantras, in 2006 the total value of global remittances flows to developing countries topped US\$220 billion (having almost doubled in the previous four years), and only foreign direct investment flows supply poorer countries with more stable currency than remittances" (Gamlen, 2008: 6). As Goldin and Reinert (2006: 176) note, developing countries governments usually welcome remittances as contributions to national development because they reduce poverty and boost living standards among recipients, and can have a stabilizing effect during periods of upheaval.

Johnson and Sedaca (2004) presents five ways in which diasporas could participate in countries of origin economy: individual financial remittances, collective financial remittances (social, infrastructure and business projects), diasporas business networks, diasporas investment instruments (diasporas, investment funds, development banks, diasporas bonds) and knowledge transfer mechanisms (professional knowledge networks, virtual knowledge and technology transfer, short-term voluntary counseling).

Koznecov also states, that emigrated citizens do not have to be investors, or contribute financially in order to have a positive impact on a national or regional development. To national or regional sustainable development members of the diaspora can contribute by being a "bridges" to a new markets, new sources of investment, new competencies, experience and other. According to Kuznetsov, influential members of diasporas can also successfully raise public debate on the new country's sustainable development projects, on possible reform plans or support their implementation (Kuznecov, 2006: 3). Similarly, "the mobilization of knowledge and skills of these expatriate professionals can play an even more effective role [in] facilitating economic development in their countries of origin [than individual or collective remittances]" (Johnson and Sedaca, 2004: 73).

Gamlen reveals that in context of 'New Growth' economic theories, which conceive of knowledge as the engine of growth, knowledge transfer became even more of interest in mitigating brain drain and promoting brain circulation: it has stimulated interest in promoting transfers of knowledge and technologies from abroad in order to promote economic growth at home (Gamlen, 2010: 7). The other type of knowledge transfer policy is based around cultivating what are sometimes called 'diaspora knowledge networks' - dispersed networks of researchers from the home country that collaborate on scientific projects in the hope of benefiting for their home country (Kuznetsov, 2006).

However, not only academic networks can contribute towards origin country development, but also business and professional networks. One example of this, provided by Ancien and others, would be the AsiaPacific Business Forum, which brings together 11 Irish Business Groups. This Forum provides opportunities to share ideas, resources and reputation. Another organization, the Irish Chamber of Commerce is a transnational economic network, which has 13 chapters in the United States. Among other networks that can also be mentioned are the Irish Technology Leadership Group in Silicon Valley (Irish elite corporation network managers who support the Irish ICT sector dissemination of Irish business ideas), BioLink (biotechnology network of professionals in the United States), Techlink UK (Irish scientists network working in London and seeking to commercialize their laboratory inventions). And more examples - Irish network in New York and San Francisco, network of Irish professionals in London (Ancien, Boyle, Kitchin, 2009: 25). Ionescu 
provide other examples of diaspora networks: the Lebanese and the Armenian diaspora, which helps connect the diaspora's and the country's of origin potential and business initiatives, or network of The Indus Entrepreneur - one of the largest networks in the Indian diaspora, which has helped India to gain trust by such investors as Helwett Packard (Ionescu, 2006: 27). These examples show how diaspora's knowledge and contacts are used in their home country's economic development.

A newly formed trend in cooperation with diasporas is development of a global networks connecting the country of origin with its diaspora. An example of this might be an international network of GlobalScot founded in 2001. This network connects more than 800 influential, valuable experience and contacts with the Scots or people with Scottish roots, who voluntarily devote their time and experience to serve the economic growth in Scotland. Learning from GlobalScot experience the similar networks were created in Chile and South Africa (Chile Global and Global South Africa) (Ancien, Boyle, Kitchin, 2009: 25). Other examples: in 2010 the Global Irish Network, which currently includes more than 300 influential Irish and Irish-related foreign persons, was created. Network members represent a wide range of business and professional fields in 40 countries. They are the source of Ireland's international experience in order to revive the economy. Network members show strong links with Ireland and have high achievements in international business relations, or the promotion of Ireland. The network is also the country's international reputation-building partner. Ionescu gives an example of Korea global network model which aims to encourage a formation of decentralized cultural, social and economic networks between Korea and the foreign communities (Ionescu, 2006: 27).

Community-based initiatives are another forms in which diaspora can contribute and support the development of their country. For example, Ionescu mentions Mexico's initiative "Programa de Iniciativas Ciudadano 3 x 1 in Mexico" which connects the diaspora funds with federal, state and municipal budgets. Another example is the Catalan Development Cooperation Fund (FCCD), which is a non-profit organization that operates mainly in Latin America and encourages diaspora willing to engage in development projects in their home country.

The aforementioned examples really does not cover all the possible ways of cooperation, however, it reveals a wide range of opportunities for the diaspora to contribute to the sustainable development of their countries of origin. In order to analyze the ways in which Lithuanian diaspora could contribute to its country's sustainable development in the next chapter the results of the research are discussed.

\section{Benefits of cooperation with the Lithuanian diaspora in the context of promoting sustainable development}

In 2009, the Government of Lithuania approved the new National Sustainable Development Strategy. A new strategy for sustainable development in Lithuania sets the priorities that include: mitigation of climate change and clean energy production, sustainable transport, sustainable consumption and production, natural resource protection and management, public health, education and the role of education, the preservation of Lithuanian cultural identity, social inclusion (poverty and social exclusion), demographic and migration processes management, global poverty and sustainable development challenges, as well as sustainable consumption and development cooperation.

In implementing this strategy, the main governmental aims are to coordinate and harmonize the basic components of sustainable development (environmental, economic and social) and the development of industries, to enable all sectors of society to participate actively in sustainable development and to jointly progress the results to the international, regional, local long-term and fundamental interests of the compatibility of the implementation of sustainable development in all spheres of life-time (National Sustainable Development Strategy, 2009: 32).

However, it is important to note that the latter document is more oriented to the inner potential of the country's sustainable development goals. Meanwhile, the Lithuanian diaspora role in contributing to national well-being creation remains unnoticed. Ethnic Minorities and Emigration Department in 2006 conducted 
the study "Lithuanian long-term strategy in respect of immigration and emigration" which highlights that in an aging society with ever increasing emigration it is particularly important to change attitudes towards Lithuanians living abroad to maximize their involvement in the life of Lithuania (Motieka, Adomenas, Daniliauskas, 2006: 127). Thus, the priorities should shift to include the diaspora to contribute to the sustainable development of their country or region.

It should be noted that recently steps were being taken to strengthen Lithuania's relations with the diaspora when it was understood that diaspora's experience can be used for the development of the Lithuanian state welfare. The Government of Lithuania in 2011 approved the resolution "Global Lithuania" - in order to create program (for year 2011-2019) of foreign citizens' involvement in public life of Lithuania ("Global Lithuania - Lithuanian foreign involvement in public life", 2011). This program aims to "provide mechanisms to encourage the Lithuanians abroad to promote the Lithuanian language, Lithuanian national identity, to strengthen the Lithuanian diaspora relations with Lithuania, and engaging in various areas of public life and contribute to well-being creation in Lithuania" ("Global Lithuania - Lithuanian foreign involvement in public life", 2011). Though the program involves the aim to strengthen the relations with the diaspora, so far these aims are directed mainly for the fostering of national identity among Lithuanian diaspora. So the demand for search of effective cooperation with the diaspora is still very important.

\section{Lithuanian diaspora priorities and ways to contribute to the country's sustainable} development

In 2012 Mykolas Riomeris university gathered researchers that conducted a qualitative research „Possibilities to use Lithuanian diaspora potential to the country's development" that analyze Lithuanian diaspora priorities and ways to contribute to the sustainable development of their country. The aim of the research was to clarify the foreign Lithuanians opinion on the most promising means of cooperation with diasporas in European countries and their application possibilities for the case of Lithuania (Gudelis, Gečiene, Jakulevičienè, 2012).

This research covers these objectives:

- To identify the factors hindering the Lithuanian diaspora to engage in the life of Lithuania.

- Discuss what are the possibilities of different Lithuanian diaspora groups to participate in the life of Lithuania and create its well-being.

- Provide guidance on the use of the diaspora potential priority areas to generate well-being of the country.

In order to discuss the aims and objectives of the research, 12 interviews with experts were conducted on January 16-22, 2012. Interview experts were selected by these criteria:

- Membership and active participation (current and former) in activities of Lithuanian communities abroad: the World Lithuanian Community, United States of America (hereinafter - the U.S.), Belgian, Spanish, Dutch and Lithuanian community in Ireland (A/N - by the place of residence the survey experts distributed as follows: 1 from Ireland, 1 from Belgium, 2 from the United States, 1 from the UK, 1 from Spain, 1 from Canada, 4 from Lithuania, 1 from the Netherlands);

- Membership and / or participation in the Lithuanian foreign organizations: the World Lithuanian Youth Union, the United Kingdom (hereinafter - UK) Lithuanian Youth Union, Lithuanian Global Leaders, Santara-Šviesa;

- Return to Lithuania after a long time spent abroad and / or membership in returned to Lithuania organizations: "Sugrižus", Futura Scientia.

It was also intended to examine the different diaspora groups representatives (education, business and culture). The research revealed that different host countries have very different diaspora groups by social characteristics and the number of members in the diaspora. Moreover, diaspora groups and their interests 
differ in terms of emigration wave, generation and diaspora members citizenship. Therefore the interests and possibilities of Lithuanian diaspora are various in engaging to origin country's development. Accordingly, the specific types of policy intervention are needed for different diaspora groups.

In general, the research results showed that the Lithuanian diaspora is willing to cooperate and contribute significantly to the country's sustainable development in various areas. However, it is important to emphasize that despite the relatively large diaspora's scientific, cultural and business potential, there is some cooperation barriers that slows the possibilities to use these benefits enough:

- the lack of initiative in foreign Lithuanian communities;

- the lack of attention to Lithuanian communities from Lithuania. This is associated with issue of citizenship, weak efforts of the Lithuanian authorities to liaise with foreign Lithuanians, and the lack of funding;

- the lack of information how diaspora can contribute to well-being of Lithuania;

- negative attitudes towards emigrants in Lithuanian society.

The research also revealed key fields and ways in which members of the diaspora can contribute to the country's well-being:

- science and education (exchange of knowledge, students practice, Lithuanian schools, joint projects, expert service and advice);

- business (mentoring and financial support to projects and investments in Lithuania, students practice in business enterprises in Lithuania and presentations for business opportunities in Lithuania);

- culture (works presentation of Lithuanian artists, their financing, organization of art festivals);

- social exclusion (support for Lithuania's social projects and institutions (such as children's homes), "invite friends to Lithuania" program, student meetings, conferences, debates, etc.).

According to the research participants expressed views, the main directions of diaspora potential use were set: to provide needed for cooperation information, to reduce the contraposition of the Lithuanian people and the diaspora, to focus on the youth involvement in development of origin country, to note and support already existing private and non-governmental initiatives, to use diaspora' knowledge and experience in all fields - science, business, culture, etc.

By providing guidance on the use of knowledge and experience of diaspora, experts stressed the importance of all scientific and business, cultural and social issues in order to create well-being in Lithuania. In the science field diaspora's potential could be useful by: representing Lithuania education abroad, improving education institutions and their activities in Lithuania, creating foreign scientists working in Lithuanian data base and attracting large investments, promoting foreign workers to include teachers and students to the Lithuanian business development, providing them with practical tasks in the internship in Lithuanian companies, and supporting initiatives aimed at attracting more researchers to Lithuania.

In business and economic field cooperation with the diaspora can help: to inform foreign business world of Lithuanian business and products, to inform about business and job opportunities in Lithuania, to organize business missions or "job fairs" where businessmen from Lithuania could present job opportunities in their companies, attract investment in Lithuania, and to raise funds in Lithuania.

In cultural and social field cooperation with the diaspora can help: to represent Lithuanian culture abroad, to organize the exchange of innovative projects promoting creativity, to utilize diaspora knowledge and experiences (called know-how) to promote cultural tourism in Lithuania, and to attract support for the social needs of Lithuania.

Experts, interviewed during the research, also proposed some forms of cooperation between diaspora and Lithuanian society: first, to support Global network of Lithuania and professional network development. It is recommended to take greater account of existing initiatives and networks under development in different areas, based on the most Lithuanian foreign ideas and the best ways to use their voluntary work in the 
creation of welfare in Lithuania. The idea is not to create a professional network "artificially", but rather to maintain and promote already developed or emerging networks.

Second, the cooperation in the field of information: detailed and relevant information to the Lithuanians abroad, and effective communication capabilities between diaspora and Lithuanian authorities. The need for information covers the following areas: information about Lithuania's initiatives, strategies, programs, about the activities in politics and government, the Government's objectives, changes in the economy, the social services and security, employment and training opportunities for non-governmental organizations and initiatives and the like. Dissemination of information to be carried out through various networks and web sites, for example, via Global Lithuanian website, with links to other networks is possible without intention to centralize all information.

Third, the database development initiative is supported by most experts as an instrument for facilitating cooperation and contact search capabilities. However, the data collection and update capabilities and data security in cyberspace is questioned. According to some experts, in order to create database efficiency and its relevance to consumers, there should be a steady database management and data processing that could be achieved by assigning responsible persons.

\section{Conclusions}

Wide Lithuanian diaspora abroad has a huge potential for contributing to the country's sustainable development. As emigration is increasing, this potential rises every year. However, the Lithuanian state's sustainable development policies are mainly focused on the country's internal capacity. Meanwhile, the Lithuanian diaspora role in contributing to national well-being creation remains unnoticed.

Recently some actions were done, in order to strengthen Lithuania's relations with the diaspora so that Lithuanian diaspora experience could be used for the development of Lithuanian national prosperity, but so far these measures are relatively limited and focused mainly for ethnic purposes for Lithuanian communities abroad. So the broader means of cooperation with the diaspora are still to be found.

Knowing the other countries good practice it can be said that Lithuanian diaspora transnational relations, networks and forms of cooperation can be quite a substantial factor in order to reinforce sustainable development strategies for engaging diasporas in the economic, scientific, and other fields.

The study showed that, despite some obstacles for Lithuanian diaspora to cooperate with origin country, Lithuanian diaspora is willing and could contribute significantly to the country's sustainable development in various areas: scientific, business, cultural and social. Therefore, the task of Lithuanian government is to decrease these barriers - lack of information how to contribute to the well-being of Lithuania and lack of attention of Lithuanian government towards diaspora potential - by implementing diaspora engagement oriented measures.

These measures should take into account the existing diversity of Lithuanian diaspora groups, to be oriented towards providing relevant and accessible information, as well as inspiring and supporting already existing and new diaspora networks and their initiatives.

\section{References}

Ancien, D., Boyle, M., Kitchin, R. (2009). Exploring Diaspora Strategies: An International Comparison. Ireland: NUIM, p. 1-39.

Gamlen, A. (2006). Diaspora Engagement Policies: What are they, and what kinds of states use them? UK: University of Oxford. Working Paper, No. 32, p. 1-31.

Gamlen, A. (2008). Why Engage Diasporas? ESRC Centre on Migration, Policy and Society. UK: University of Oxford. Working Paper, No. 63, p. 1-17.

Gamlen, A. (2010). People on the Move: Managing Migration in Today's Commonwealth (The First Report of the Ramphal Commission on Migration and Development in the Commonwealth). London: The Ramphal Centre.

Gamlen, A. (2011). Engaging Asia: The Role of the Diaspora. Outlook Report 15. Wellington: Asia New Zeland Foundation.

Global Lithuania - Lithuanian foreign involvement in public life - program of the year 2011-2019. Government Order, No. 389 of the 2011 March 30. 
Gudelis, D., Gečienė, I., Jakulevičienė, L. (2012). Lietuvos diasporos potencialo panaudojimas valstybès gerovei kurti: Europos Sajungos šaliu nariu geroji praktika [The use of Lithuanian diaspora potential for well - being of state]. Vilnius: MRU.

Ionesku, D. (2006). Engaging Diasporas as Development Partners for Home and Destination Countries: Challenges for Policymakers. Geneva: IOM, No. 26, p. 1-89.

Johnson, B., Sedaca, S. (2004). Diasporas, Émigrés and Development: Economic Linkages and Programmatic Responses. A Special Study of the U.S. Agency for International Development (USAID). Trade Enhancement for the Services Sector (TESS) Project.

Lithuanian Foreign communities. Access via the Internet: http://www.urm.lt/index.php?-1923348399

LR Vyriausybès nutarimas Nr. 389 dèl „, Globalios Lietuvos“ - užsienio lietuviu issitraukimo ì valstybès gyvenimq - kūrimo 2011-2019 metu programos patvirtinimo $2011 \mathrm{~m}$. kovo 30 d. [Lithuanian Government Order No. 389 of the "Global Lithuania" - Lithuanians abroad involvement in public life - creation for 2011-2019 program confirmation. March 30, 2011 ].

Nacionaline darnaus vystymosi strategija. (2009). Rugsėjo 16 d., Nr. 1247 [The National Strategy for Sustainable Development. September 16, 2009, No. 1247].

Kathleen, N., Erin, P. (2004). Beyond Remittances: The Role of Diaspora in Poverty Reduction in their Countries of Origin. Washington, D.C.: MPI, p. 1-51.

Kuznetsov, Y. (ed.) (2006). Diaspora Networks and the International Migration of Skills: How Countries Can Draw on Their Talent Abroad. WBI Development Studies. Washington, D.C.: World Bank, p. 1-12.

Lindsay, B. (2004). Diaporas and Economic Development: State of Knowledge. Washinton, D.C.: Georgetown University.

Motieka, E., Adomėnas, M., Daniliauskas, J. (2006). Lietuvos valstybès ilgalaike strategija lietuviu emigracijos ir išeivijos atžvilgiu. Vilnius: Strateginių studijų centras.

"The task for Lithuania - from brain drain to brain attraction". The project "Brain Drain Program Development and Implementation" final edition. (2008).

Vertovec, S. (2005). The Political Importance of Diasporas, Centre on Migration, Policy and Society. UK: University of Oxford. Working Paper, No. 13, p. 1-13.

\section{LIETUVIU DIASPORU VAIDMUO, SIEKIANT DARNAUS SALIES VYS TYMO}

Ingrida GeČIEnE, ŠSARŪNAs Matulaitis

Socialinių inovacijų institutas (Lietuva)

\section{Santrauka}

Skirtingų pasaulio šalių ir jų diasporų bendravimo bei bendradarbiavimo patirtis rodo daug skirtingų būdų, kaip diasporos gali prisidèti prie tvaraus savo šalies vystymosi. Lietuva turi gana didelę diasporą, kuri galètų nemažai prisidèti prie savo šalies vystymosi. Vis didejjantys emigracijos mastai nuolat didina lietuvių, gyvenančių užsienyje, skaičių, ypač pastaraisiais metais. Taigi lietuvių mokslinis, kultūrinis ir ekonominis potencialas už Lietuvos ribų nuolat auga. Deja, šie pokyčiai ir didelis diasporos potencialas vis dar yra menkai suvokti ir panaudojami Lietuvoje.

Siekiant išsiaiškinti diasporos potenciala, $2012 \mathrm{~m}$. atliktas Lietuvių diasporos požiūrio ir galimybių prisidèti prie savo šalies vystymosi tyrimas: atlikta 12 interviu su užsienio lietuvių bendruomenių ir organizaciju vadovais. Tyrimo rezultatai atskleide, kad lietuvių diasporos nariai nori ir turi galimybių reikšmingai prisidèti prie tvaraus šalies vystymosi ịvairiose srityse: mokslo, verslo, kultūros ir socialinèje. Siekdama skatinti tokį bendradarbiavimą Lietuvos Vyriausybẻ turètų padèti ịveikti čia iškylančias kliūtis ir igyvendinti priemones, kad būtų atsižvelgiama ị ịvairių išeivių grupių interesus bei galimybes, teikti informaciją apie galimybes bendrauti ir bendradarbiauti, remti esamus ir naujus diasporos tinklus bei jų iniciatyvas.

PAGRINDINIAI ŽODŽIAI: lietuviu diaspora, tarptautinis bendradarbiavimas, darnus vystymasis, regioninis vystymasis.

JEL KLASIFIKACIJA: Q010, Q560. 